\title{
Charakterystyka parametrów sprężystych określonych na podstawie pomiarów geofizyki otworowej i modelowań teoretycznych w wybranych formacjach w otworach basenu bałtyckiego i wierconych na szelfie
}

\begin{abstract}
W niniejszej pracy zawarto wyniki badań parametrów sprężystych pomierzonych akustyczną sondą dipolową lub obliczonych na podstawie teoretycznych modeli z kilku otworów położonych w basenie bałtyckim i trzech na szelfie. Badania ograniczono do pięciu formacji, poczynając od charakterystycznego poziomu sylurskiego ogniwa mułowców wapnistych z Redy, stanowiącego reper sejsmiczny Sb, a kończąc na kambrze środkowym - poziom Paradoxides paradoxissimus (PP). Zauważono pewne podobieństwa w kształtowaniu się takich parametrów sprężystych jak: prędkości fal podłużnych i poprzecznych, modułów Younga, odkształcenia objętości i postaci - w analizowanych otworach basenu bałtyckiego i odwierconych na szelfie. Otwory te znajdują się w strefie średniej perspektywności dla ropy naftowej i kondensatu oraz dobrej dla gazu ziemnego [14]. Przedstawiona charakterystyka parametrów sprężystych może być wykorzystana w modelowaniach sejsmicznych do badania zmienności poziomów stratygraficznych i wyjaśnienia szeregu problemów pojawiających się przy zintegrowanej interpretacji danych geofizyki otworowej i sejsmicznych pól falowych. Wspomaga również ocenę skał ilastych pod kątem prognozowania zabiegów szczelinowania hydraulicznego i udostępniania węglowodorów ze skał zbiornikowych o niskich przepuszczalnościach. Skały te charakteryzują się zróżnicowaną „kruchością” (brittleness), którą można rozpatrywać w aspekcie składu mineralnego i parametrów sprężystych, takich jak współczynnik Poissona, moduł Younga, moduł odkształcenia objętości, postaci oraz stałe Lamégo.
\end{abstract}

Słowa kluczowe: gaz z łupków, parametry sprężyste, moduł Younga, współczynnik Poissona, basen bałtycki, geofizyka otworowa.

\section{Characteristics of elastic parameters determined on the basis of well logging measurements and theoretical modeling, in selected formations in boreholes in the Baltic Basin and the Baltic offshore}

The paper shows the results of studies of elastic parameters determined on the basis of well acoustic measurements and theoretically modeled in selected boreholes located in the Baltic Basin and offshore Baltic Sea. The study was limited to five formations, starting from the characteristic level of the Silurian Reda calcareous sandstone Member, which is the seismic $\mathrm{Sb}$ benchmark and ending with the Middle Cambrian level Paradoxides Paradoxissimus (PP). It was noted, that there were similarities in the distribution of the elastic parameters, such as the velocity of compressed and shear waves, dynamic Young's modulus, bulk and shear moduli in analyzed boreholes in the Baltic Basin and those drilled in the shelf. These boreholes are located in a zone of average prospects for oil and condensate and good for natural gas [14]. The presented characteristics of elastic parameters may be used in seismic modeling to study the variability of stratigraphic levels and to clarify a number of problems occurring during the integrated data interpretation of well logs and seismic wave fields. It also supports the evaluation of clay rocks for the prediction of hydraulic fracturing and the production of hydrocarbons from reservoir rocks with low permeability. Sedimentary rocks are differentiated in brittleness, which can be seen in terms of the mineral composition and elastic parameters, such as Poisson's ratio, Young's modulus, and bulk and shear moduli as well as Lamé's constant.

Key words: shale gas, elastic parameters, Young's modulus, Poisson's ratio, Baltic Basin, well logging. 


\section{Wprowadzenie}

Obliczono parametry sprężyste dla trzech otworów położonych w strefie szelfowej i pięciu w basenie bałtyckim. Wybrano następujące otwory: B8-Z4, B8-Z5 i B21/2, z których dwa pierwsze zostały odwiercone na koncesji eksploatacyjnej złoża ropy naftowej B8 w rejonie Rozewie. Trzeci otwór rozpoznawczy, B-21/2, znajduje się na obszarze morskim RP w południowo-zachodniej części syneklizy bałtyckiej, na bloku Łeba.

Otwory położone w basenie bałtyckim to L-1, O-2, K-1, B-1, W-1, leżące wzdłuż osi NNW-SSE (rysunek 1).
Analizę porównawczą przeprowadzono dla pięciu wybranych serii litostratygraficznych, poczynając od sylurskiego poziomu mułowców wapnistych z Redy ( $\mathrm{Sb}$ ), poprzez sylurskie ogniwo iłowców bitumicznych z Jantaru, ordowicką formację łupków z Sasina, ordowickie wapienie z Kopalina, a kończąc na kambrze środkowym poziomu Paradoxides paradoxissimus (PP).

W tablicy 1, dla przykładu, zestawiono wybrane statystyki opisowe parametrów sprężystych dla trzech serii w otworach położonych na szelfie: B8-Z4, B8-Z5 i B21/2.

Do określania parametrów sprężystych wykorzystano dane z pomiarów akustycznej sondy dipolowej oraz wyniki uzyskane przy użyciu programu Estymacja TP i wariantu teoretycznego modelu Biota-Gassmanna [4]. Zastosowano ostatnią wersję programu, uzupełnioną o opcję z automatycznym przeliczaniem gęstości i modułów sprężystości dla gazu, ropy i wody ze zmianą ciśnienia, temperatury i składu chemicznego mediów złożowych [5].

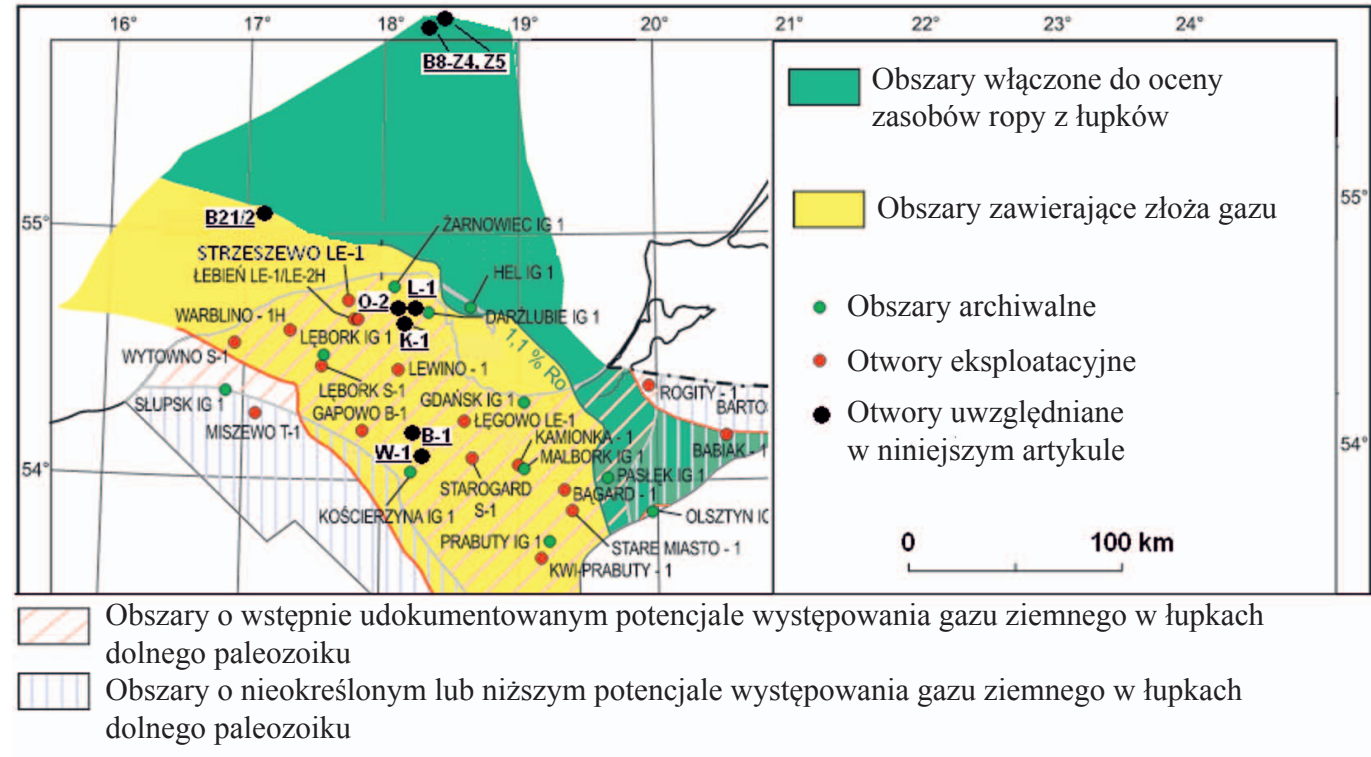

Rys. 1. Fragment mapy z położeniem analizowanych otworów (zaznaczonych kolorem czarnym) w basenie bałtyckim [13] (zmodyfikowane)

Tablica 1. Statystyki opisowe parametrów sprężystych dla wybranych poziomów w otworach na szelfie bałtyckim

\begin{tabular}{|c|c|c|c|c|}
\hline \multirow{2}{*}{ Stratygrafia } & \multirow{2}{*}{$\begin{array}{l}\text { Parametr: } \\
\text { obraz falowy } \\
\text { model } \mathbf{B G}\end{array}$} & \multicolumn{3}{|c|}{$\begin{array}{l}\text { Nazwy otworów } \\
\text { Wartość średnia; przedział zmienności }\end{array}$} \\
\hline & & B8-Z4 & B8-Z5 & B-21/2 \\
\hline \multirow{8}{*}{$\begin{array}{l}\text { Sylur } \\
\text { Ogniwo łupków } \\
\text { bitumicznych } \\
\text { z Jantaru }\end{array}$} & & $2159,61 \div 2163,23$ & $2137,5 \div 2147,5$ & $1652,8 \div 1667,98$ \\
\hline & $\begin{array}{l}\mathrm{VP}[\mathrm{km} / \mathrm{s}] \\
\text { VPEQ }\end{array}$ & $\begin{array}{c}\text { brak danych } \\
\mathbf{3 , 1 3 7 ;} \mathbf{3 , 0 3 7 \div 3 , 8 5 0}\end{array}$ & $\begin{array}{l}3,618 ; 3,049 \div 4,384 \\
\mathbf{3 , 5 6 5 ;} \mathbf{3 , 2 0 3} \div \mathbf{4 , 2 6 0}\end{array}$ & $\begin{array}{l}3,403 ; 3,096 \div 4,224 \\
\mathbf{3 , 4 7 7} ; \mathbf{2 , 9 6 4 \div 4 , 5 5 1}\end{array}$ \\
\hline & $\begin{array}{l}\mathrm{VS}[\mathrm{km} / \mathrm{s}] \\
\text { VSEQ }\end{array}$ & $\begin{array}{c}\text { brak danych } \\
1,639 ; 1,569 \div 2,247\end{array}$ & $\begin{array}{l}1,940 ; 1,801 \div 2,091 \\
\mathbf{1 , 8 6 1 ;} \mathbf{1 , 6 5 9} \div \mathbf{2 , 2 2 0}\end{array}$ & $\begin{array}{l}1,824 ; 1,678 \div 2,380 \\
\mathbf{1 , 8 6 7} ; \mathbf{1 , 4 7 6} \div \mathbf{2 , 4 2 6}\end{array}$ \\
\hline & $\begin{array}{l}\mathrm{Vp} / \mathrm{VS} \\
\text { VPEQ/VSEQ }\end{array}$ & $\begin{array}{c}\text { brak danych } \\
1,918 ; 1,713 \div 1,935\end{array}$ & $\begin{array}{l}1,848 ; 1,669 \div 2,049 \\
\mathbf{1 , 9 1 6} ; \mathbf{1 , 7 4 1} \div \mathbf{1 , 9 3 2}\end{array}$ & $\begin{array}{l}1,866 ; 1,759 \div 2,005 \\
\mathbf{1 , 8 6 7 ;} \mathbf{1 , 7 2 2} \div \mathbf{2 , 0 0 9}\end{array}$ \\
\hline & $\begin{array}{l}\text { POIS } \\
\text { NIEQ }\end{array}$ & $\begin{array}{c}\text { brak danych } \\
\mathbf{0 , 3 1 2 ; 0 , 2 4 2 \div 0 , 3 1 8}\end{array}$ & 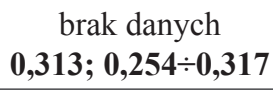 & $\begin{array}{c}\text { brak danych } \\
\mathbf{0 , 2 9 7 ; 0 , 2 4 6 \div 0 , 3 3 5}\end{array}$ \\
\hline & $\begin{array}{l}\mathrm{E}[\mathrm{GPa}] \\
\mathbf{E E Q}\end{array}$ & $\begin{array}{c}\text { brak danych } \\
17,77 ; 15,94 \div 32,97\end{array}$ & $\begin{array}{c}\text { brak danych } \\
23,64 ; 18,47 \div 33,62\end{array}$ & $\begin{array}{c}16,0 \div 21,0 \\
\mathbf{2 3 , 8 5} ; \mathbf{1 4 , 5 5} \div \mathbf{4 0 , 6 3}\end{array}$ \\
\hline & $\begin{array}{l}\mathrm{K}[\mathrm{GPa}] \\
\mathbf{K E Q}\end{array}$ & $\begin{array}{c}\text { brak danych } \\
15,69 ; 14,59 \div 21,28\end{array}$ & $\begin{array}{c}\text { brak danych } \\
21,01 ; \mathbf{1 6 , 8 0 \div 2 9 , 5 9}\end{array}$ & $\begin{array}{c}12,0 \div 15,0 \\
\mathbf{1 9 , 5 4} ; \mathbf{1 4 , 7 1 \div 3 4 , 1 2}\end{array}$ \\
\hline & $\begin{array}{l}\mu[\mathrm{GPa}] \\
\text { MIEQ }\end{array}$ & $\begin{array}{c}\text { brak danych } \\
\mathbf{6 , 7 8 ; 6 , 0 4 8 \div 1 3 , 2 9}\end{array}$ & $\begin{array}{c}\text { brak danych } \\
\mathbf{9 , 0 1 ; 7 , 0 2 \div 1 2 , 8 3}\end{array}$ & $\begin{array}{c}6,0 \div 7,0 \\
\mathbf{9 , 5 2} ; \mathbf{6 , 7 3} \div \mathbf{1 4 , 9 6}\end{array}$ \\
\hline
\end{tabular}


cd. Tablica 1

\begin{tabular}{|c|c|c|c|c|}
\hline \multirow{2}{*}{ Stratygrafia } & \multirow{2}{*}{$\begin{array}{l}\text { Parametr: } \\
\text { obraz falowy } \\
\text { model } \boldsymbol{B} \boldsymbol{G}\end{array}$} & \multicolumn{3}{|c|}{$\begin{array}{c}\text { Nazwy otworów } \\
\text { Wartość średnia; przedział zmienności }\end{array}$} \\
\hline & & B8-Z4 & B8-Z5 & B-21/2 \\
\hline \multirow{8}{*}{$\begin{array}{l}\text { Ordowik ilasto- } \\
\text { mułowcowy } \\
\text { Formacja z Sasina }\end{array}$} & & $2169,5 \div 2225,5$ & $2147,5 \div 2186,5$ & $1668,0 \div 1725,0$ \\
\hline & $\begin{array}{l}\mathrm{VP}[\mathrm{km} / \mathrm{s}] \\
\text { VPEQ }\end{array}$ & $\begin{array}{c}\text { brak danych } \\
3,915 ; 3,130 \div 4,983\end{array}$ & $\begin{array}{c}\text { brak danych } \\
4,138 ; 3,186 \div 5,291\end{array}$ & $\begin{array}{l}3,680 ; 3,057 \div 4,723 \\
\mathbf{3 , 6 8 1} \mathbf{2 , 8 4 8} \div \mathbf{4 , 7 4 5}\end{array}$ \\
\hline & $\begin{array}{l}\mathrm{VS}[\mathrm{km} / \mathrm{s}] \\
\text { VSEQ }\end{array}$ & $\begin{array}{c}\text { brak danych } \\
\mathbf{2 , 0 4 6 ; 1 , 6 1 8 \div 2 , 8 0 5}\end{array}$ & $\begin{array}{c}\text { brak danych } \\
\mathbf{2 , 1 6 3 ;} \mathbf{1 , 6 4 5 \div 2 , 7 8 0}\end{array}$ & $\begin{array}{l}1,986 ; 1,429 \div 2,623 \\
\mathbf{2 , 0 6 4 ;} \mathbf{1 , 4 8 0} \div \mathbf{2 , 6 2 8}\end{array}$ \\
\hline & $\begin{array}{l}\mathrm{Vp} / \mathrm{VS} \\
\text { VPEQ/VSEQ }\end{array}$ & $\begin{array}{c}\text { brak danych } \\
1,917 ; 1,689 \div 2,021\end{array}$ & $\begin{array}{c}\text { brak danych } \\
1,914 ; 1,883 \div 1,946\end{array}$ & $\begin{array}{l}1,860 ; 1,369 \div 2,403 \\
\mathbf{1 , 7 8 3} ; \mathbf{1 , 6 1 0} \div \mathbf{1 , 9 2 5}\end{array}$ \\
\hline & $\begin{array}{l}\text { POIS } \\
\text { NIEQ }\end{array}$ & $\begin{array}{c}\text { brak danych } \\
\mathbf{0 , 3 1 1 ; 0 , 2 3 0 \div 0 , 3 3 8}\end{array}$ & $\begin{array}{c}\text { brak danych } \\
\mathbf{0 , 3 1 2 ; 0 , 3 0 4 \div 0 , 3 2 1}\end{array}$ & $\begin{array}{c}\text { brak danych } \\
\mathbf{0 , 2 6 8 ; 0 , 1 8 6 \div 0 , 3 1 5}\end{array}$ \\
\hline & $\begin{array}{l}\text { E }[\mathrm{GPa}] \\
\text { EEQ }\end{array}$ & $\begin{array}{c}\text { brak danych } \\
29,47 ; 17,59 \div 53,33\end{array}$ & $\begin{array}{c}\text { brak danych } \\
32,68 ; \mathbf{1 8 , 1 5} \div \mathbf{5 3 , 7 2}\end{array}$ & $\begin{array}{c}\text { brak danych } \\
\mathbf{2 8 , 4 3 ;} \mathbf{1 5 , 0 5 \div 4 7 , 2 0}\end{array}$ \\
\hline & $\begin{array}{l}\mathrm{K}[\mathrm{GPa}] \\
\mathbf{K E Q}\end{array}$ & $\begin{array}{l}\text { brak danych } \\
\mathbf{2 6 , 1 0 ; 1 6 , 0 6 \div 4 3 , 5 2}\end{array}$ & $\begin{array}{c}\text { brak danych } \\
\mathbf{2 8 , 9 1 ; 1 6 , 6 5 \div 4 7 , 3 6}\end{array}$ & $\begin{array}{c}\text { brak danych } \\
\mathbf{2 0 , 7 9 ;} \mathbf{1 3 , 5 6 \div 3 5 , 5 6}\end{array}$ \\
\hline & $\begin{array}{l}\mu[\mathrm{GPa}] \\
\text { MIEQ }\end{array}$ & $\begin{array}{l}\text { brak danych } \\
11,26 ; 6,68 \div 21,05\end{array}$ & $\begin{array}{l}\text { brak danych } \\
12,46 ; 6,88 \div 20,49\end{array}$ & $\begin{array}{l}\text { brak danych } \\
\mathbf{1 1 , 2 0 ; 5 , 7 2 \div 1 8 , 4 5}\end{array}$ \\
\hline \multirow{9}{*}{$\begin{array}{l}\text { Ordowik } \\
\text { wapienie }\end{array}$} & & $2225,5 \div 2237,5$ & $2197,5 \div 2214,4$ & $1732,0 \div 1760,0$ \\
\hline & $\begin{array}{l}\mathrm{VP}[\mathrm{km} / \mathrm{s}] \\
\text { VPEQ }\end{array}$ & $\begin{array}{l}5,097 ; 4,542 \div 5,930 \\
\mathbf{5 , 0 3 7 ;} \mathbf{4 , 4 3 6} \div \mathbf{5 , 4 1 2}\end{array}$ & $\begin{array}{c}\text { brak danych } \\
5, \mathbf{1 1 2} ; \mathbf{4 , 3 9 5 \div 5 , 6 2 3}\end{array}$ & $\begin{array}{l}4,964 ; 4,683 \div 5,186 \\
\mathbf{4 , 8 0 1 ;} \mathbf{4 , 5 6 9} \div \mathbf{5 , 0 4 9}\end{array}$ \\
\hline & $\begin{array}{l}\text { VS }[\mathrm{km} / \mathrm{s}] \\
\text { VSEQ }\end{array}$ & 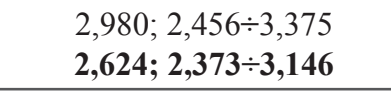 & $\begin{array}{c}\text { brak danych } \\
\mathbf{2 , 6 7 9 ;} \mathbf{2 , 2 9 1 \div 2 , 9 5 8}\end{array}$ & $\begin{array}{l}2,583 ; 2,460 \div 2,732 \\
\mathbf{2 , 6 3 3} ; \mathbf{2 , 4 9 5} \div \mathbf{2 , 7 8 2}\end{array}$ \\
\hline & $\begin{array}{l}\mathrm{Vp} / \mathrm{VS} \\
\text { VPEQ/VSEQ }\end{array}$ & $\begin{array}{c}1,72 ; 1,42 \div 2,07 \\
\mathbf{1 , 9 2 0} ; \mathbf{1 , 6 8 0} \div \mathbf{1 , 9 8 3}\end{array}$ & $\begin{array}{c}1,87 ; 1,67 \div 1,96 \\
\mathbf{1 , 9 0 8 ;} \mathbf{1 , 8 9 6} \div \mathbf{1 , 9 1 9}\end{array}$ & $\begin{array}{l}1,921 ; 1,873 \div 1,968 \\
\mathbf{1 , 8 2 3} \mathbf{1 , 8 0 9} \div \mathbf{1 , 8 3 2}\end{array}$ \\
\hline & $\begin{array}{l}\text { POIS } \\
\text { NIEQ }\end{array}$ & 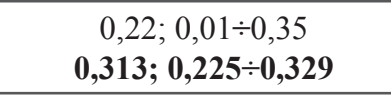 & 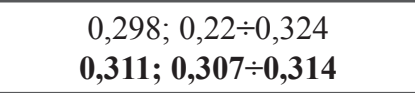 & $\begin{array}{c}\text { brak danych } \\
\mathbf{0 , 2 8 5} ; \mathbf{0 , 2 8 0} \div \mathbf{0 , 2 8 8}\end{array}$ \\
\hline & $\begin{array}{l}\mathrm{E}[\mathrm{GPa}] \\
\mathbf{E E Q}\end{array}$ & $\begin{array}{c}53,98 ; 36,5 \div 57,7 \\
\mathbf{4 7 , 7 1} ; \mathbf{3 9 , 0 0} \div \mathbf{6 2 , 1 5}\end{array}$ & $\begin{array}{l}53,18 ; 46,45 \div 60,41 \\
\mathbf{4 8 , 8 7} ; \mathbf{3 6 , 0 1} \div \mathbf{6 1 , 7 2}\end{array}$ & $\begin{array}{c}30,0 \div 45,0 \\
\mathbf{4 8 , 0 4} \mathbf{4 3 3 , 0 3 \div 5 3 , 4 7}\end{array}$ \\
\hline & $\begin{array}{l}\mathrm{K}[\mathrm{GPa}] \\
\mathbf{K E Q} \\
\end{array}$ & $\begin{array}{c}34,9 ; 15,7 \div 56,3 \\
\mathbf{4 2 , 7 8 ; ~} \mathbf{3 2 , 4 2} \div \mathbf{5 1 , 5 5}\end{array}$ & $\begin{array}{l}44,68 ; 27,65 \div 56,92 \\
\mathbf{4 3 , 9 0 ;} \mathbf{3 2 , 1 9} \div \mathbf{5 3 , 7 8}\end{array}$ & $\begin{array}{c}40,0 \div 55,0 \\
\mathbf{3 7 , 2 0} ; \mathbf{3 3}, \mathbf{7 4} \div \mathbf{4 0 , 8 6}\end{array}$ \\
\hline & $\begin{array}{l}\mu[\mathrm{GPa}] \\
\text { MIEQ }\end{array}$ & $\begin{array}{c}22,41 ; 14,0 \div 23,6 \\
\mathbf{1 8 , 1 8} ; \mathbf{1 5 , 0 0} \div \mathbf{2 5 , 3 6}\end{array}$ & $\begin{array}{l}20,54 ; 18,02 \div 22,93 \\
\mathbf{1 9 , 0 2} ; \mathbf{1 3 , 7 1 \div 2 3 , 5 8}\end{array}$ & $\begin{array}{c}13,0 \div 14,0 \\
\mathbf{1 8 , 7 0 ;} \mathbf{1 6 , 7 1 \div 2 0 , 8 5}\end{array}$ \\
\hline & & $\begin{array}{l}\text { Elewacja stołu wiertniczego: } \\
+27 \text { m. } \\
\text { Głębokość wody: } 82,5 \mathrm{~m} \text {. } \\
\text { RT - rotary table - stół } \\
\text { wiertniczy obrotowy. }\end{array}$ & $\begin{array}{l}\text { Wszystkie głębokości pre- } \\
\text { zentowane (B8-Z5) w ni- } \\
\text { niejszej dokumentacji od- } \\
\text { noszą się do miary wiertni- } \\
\text { czej, punkt odniesienia stano- } \\
\text { wi poziom stołu wiertniczego } \\
\text { RT - /+/27,0 m n.p.m. } \\
\text { Głębokość wody w miej- } \\
\text { scu posadowienia platformy } \\
\text { wiertniczej: } 82,5 \text { m. }\end{array}$ & $\begin{array}{l}\text { Kambr górny Cm3 na głę- } \\
\text { bokości od } 1760,0 \text { m do } \\
1790,0 \text { m. } \\
\text { Głębokość wody: } 79,5 \mathrm{~m} \text {. } \\
\text { Głębokości prezentowane } \\
\text { w dokumentacji podawane są } \\
\text { od poziomu stołu wiertnicze- } \\
\text { go według miary wiertniczej. } \\
\text { MD/TVD (+31,7 m n.p.m). }\end{array}$ \\
\hline
\end{tabular}

Tablica 1 zawiera wartości średnie oraz minimalne i maksymalne dla każdego parametru z wybranych poziomów. Czcionką normalną zaznaczono parametry określone na podstawie interpretacji obrazów falowych (dane z dokumentacji otworów lub obliczone na podstawie wyników podanych w plikach las). Czcionką bold zaznaczono wartości obliczone programem Estymacja TP modelem Biota-Gassmanna. Podobne zestawienia wykonano w analizowanych otworach w części lądowej basenu bałtyckiego. Tablice z obliczonymi wartościami parametrów sprężystych zamieszczone są w [20]. 


\section{Utwory syluru - poziom reperowy Sb}

We wszystkich otworach występuje charakterystyczne ogniwo mułowców wapnistych z Redy, stanowiące reper sejsmiczny Sb. Jego miąższość w otworach na szelfie waha się od $10 \mathrm{~m}$ (B8-Z4) do $15 \mathrm{~m}$ (B21/2), a w basenie baltyckim od $16 \mathrm{~m}$ (L-1) do 33,5 m (W-1). Zaznacza się też wyraźne obniżanie poziomu w kierunku S (strop w otworze B21/2 na głębokości 1142,5 m, a w W-1 na głębokości 2479,0 m).

$\mathrm{Na}$ rysunku 2 zaprezentowano fragmenty obliczonych i pomierzonych krzywych w utworach syluru (ludlow), w interwale występowania poziomu reperowego $\mathrm{Sb}$ w otworze K-1. Profil litologiczny, zamieszczony na ścieżce 9, oraz nasycenie w objętości porów (ścieżka 6) są wynikiem modelu interpretacyjnego przyjętego przez zespół Geofizyka Torun S.A.

Rysunek 3 prezentuje podobne zestawienie obliczonych i pomierzonych krzywych w utworach syluru w interwale występowania poziomu reperowego Sb w otworze B8-Z5. Jak widać, poziom $\mathrm{Sb}$ ma nieco mniejszą miąższość $(11,0 \mathrm{~m}) \mathrm{w}$ stosunku do poziomu pokazanego na rysunku 2. Granice zaznaczono zgodnie $\mathrm{z}$ danymi przedstawionymi $\mathrm{w}$ dokumentacji otworu, chociaż na podstawie analizy wyników zaprezentowanych na rysunku 3 można stwierdzić, że mogłyby być one nieco przesunięte.

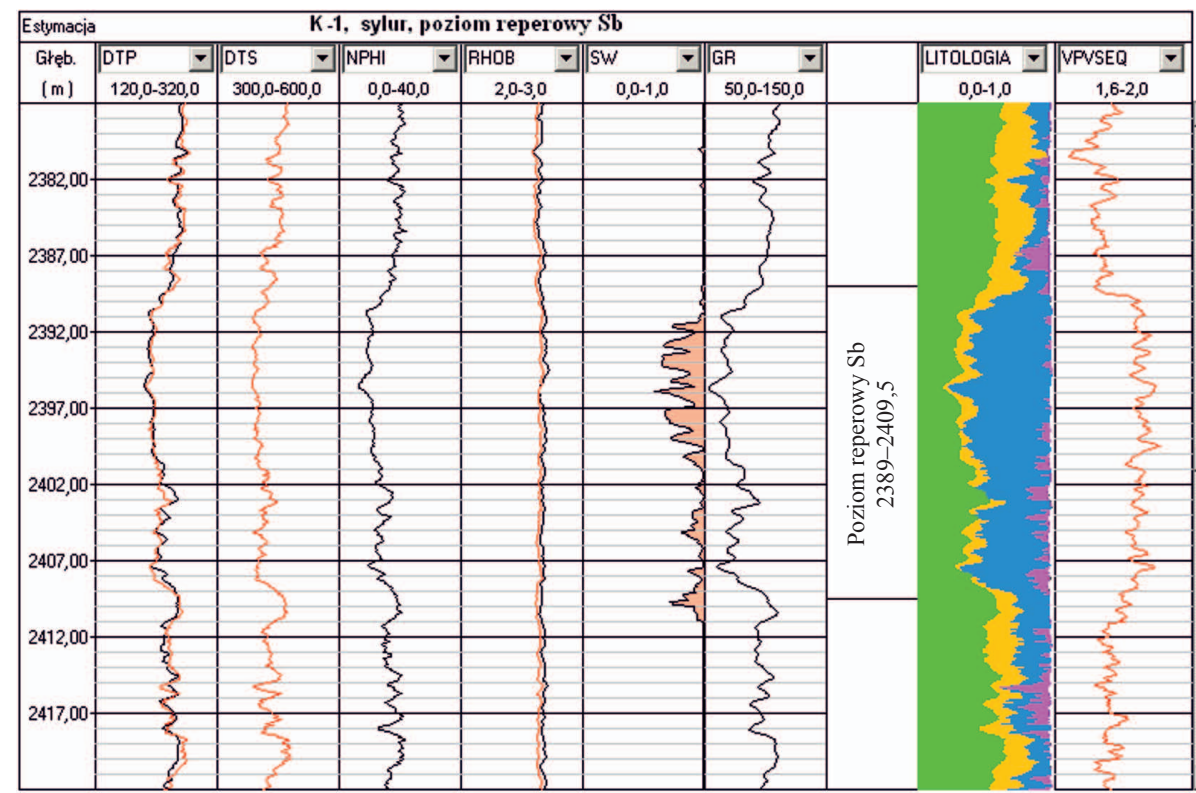

Rys. 2. Fragment obliczonych i pomierzonych krzywych w utworach syluru w interwale występowania poziomu reperowego Sb w otworze K-1. Granice poziomu zaznaczono według dokumentacji wynikowej otworu. Oznaczenia litologii: zailenie - barwa zielona, wapienie - barwa niebieska, dolomity - barwa różowa, kwarc - barwa żółta, oznaczenie nasycenia: SW - barwa biała, SG - barwa różowa

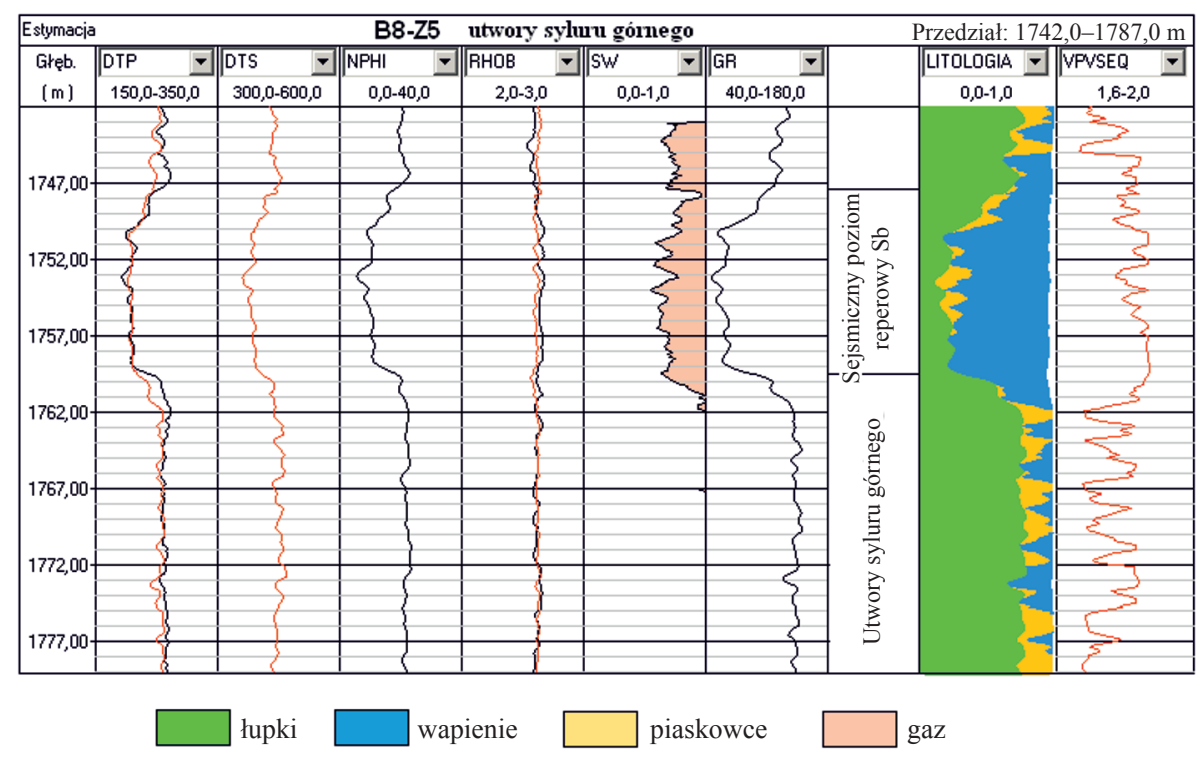

Rys. 3. Fragment obliczonych i pomierzonych krzywych w utworach syluru $\mathrm{w}$ interwale występowania poziomu reperowego $\mathrm{Sb}$ w otworze B8-Z5. Granice poziomu zaznaczono według dokumentacji wynikowej otworu. Pomiary geofizyczne w otworze wykonane zostały przez grupę geofizyki wiertniczej LOTOS

Petrobaltic S.A. oraz grupę pomiarową Geofizyki Toruń S.A., a dokumentacja geofizyczna przez firmę Geofizyka Toruń S.A.

\section{Utwory syluru - ogniwo iłowców bitumicznych z Jantaru i osady ordowickie - formacja iłowców z Sasina}

W dalszej kolejności porównano utwory syluru dolnego, ogniwo iłowców bitumicznych z Jantaru oraz osady ordowickie z formacją iłowców z Sasina. Rysunki 4a i 4b przed- stawiają te ważne z punktu widzenia poszukiwania sweet spotów utwory. Podobnym zagadnieniem zajmowano się w [17], analizując cechy formacji łupkowych determinujące 
ich perspektywiczność jako niekonwencjonalnych złóż węglowodorów.

Rysunki zestawiono w kolejności: 4a) L-1, 4b) K-1. W ogniwie iłowców bitumicznych i formacji z Sasina wyinterpretowano podwyższone zawartości substancji organicznej TOC $_{\text {obj. }}$, na rysunkach zaznaczone kolorem czerwonym (ścieżka 9). Zmienny skład mineralogiczny: zawartość kwarcu (kolor żółty), illitu (kolor zielony), kalcytu (kolor niebieski) i dolomitu (kolor różowy) odzwierciedla się w postaci zmiennych wartości parametrów sprężystych i gęstości objętościowej.

Obok wyników interpretacji parametrów sprężystych przedstawiono: na rysunku 4a zapis obrazu dynamicznego sondą XRMI (X-tended Range Micro Imager-electrical mi- croscanner) - fragment formacji iłowców z Sasina (dokumentacja otworu L-1), a na rysunku 4b - fragment zdjęcia rdzenia zestawiony z pomiarami XRMI dla formacji z Sasina z otworu K-1 (dokumentacja wynikowa otworu K-1). Widać bardzo zróżnicowany charakter tych utworów.

$Z$ analiz laboratoryjnych i pomiarów geofizycznych wynika, że w otworach z szelfu interesujący pod względem nasyceń bituminami jest poziom sylurski w landowerze, odpowiadający ogniwu iłowców z Jantaru. W otworze B8-Z5, na głębokości od 2136,5 m do 2143,8 m, poziom ten charakteryzuje się znacznie podwyższoną zawartością TOC - od 1,5\% do 15\% (dokumentacja otworu B8-Z5). Podobnie w otworze B8-Z4 podwyższoną zawar-
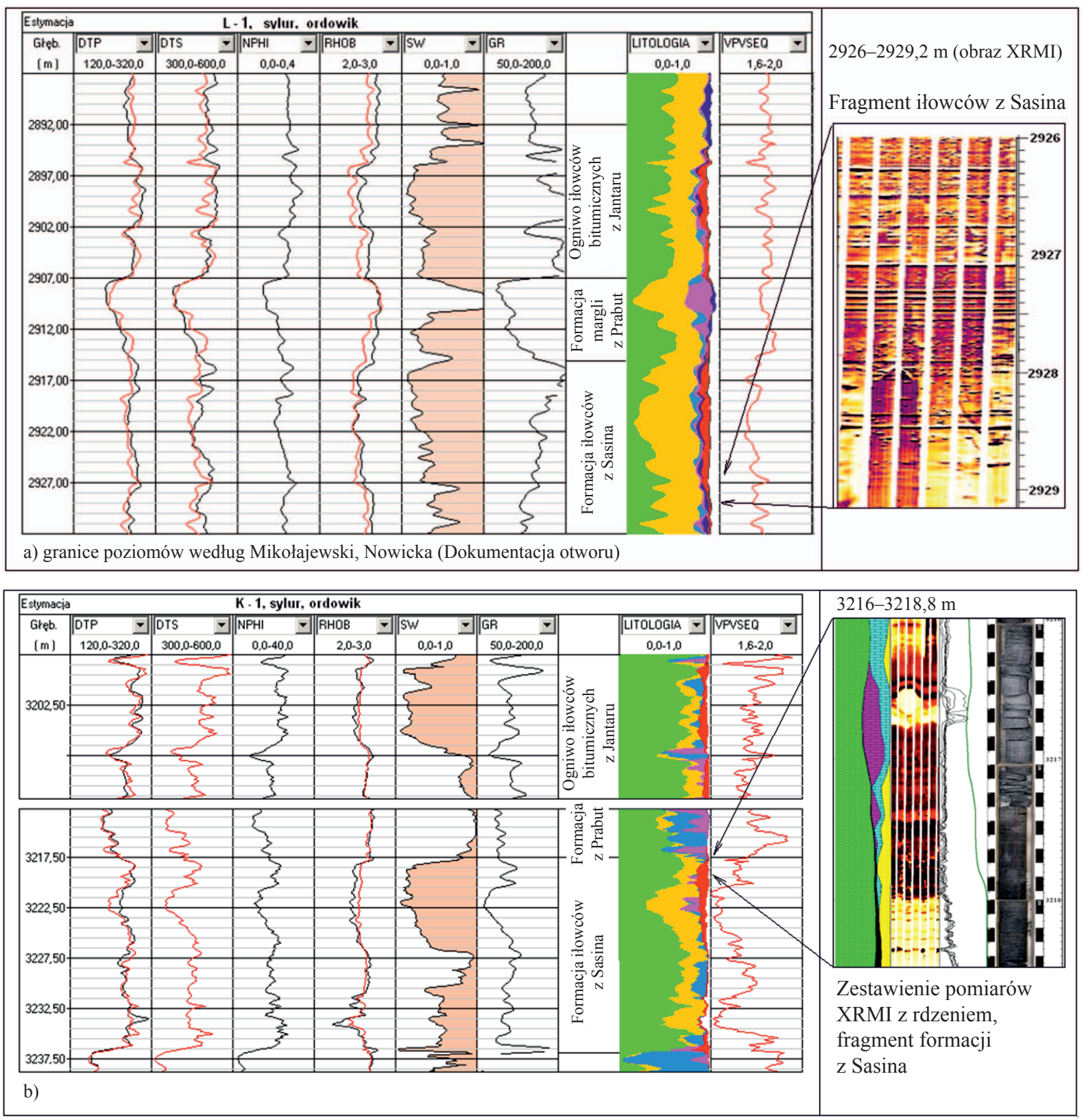

Rys. 4. Fragmenty wyinterpretowanych i pomierzonych krzywych w utworach należących do ogniwa iłowców bitumicznych z Jantaru, formacji margli z Prabut i formacji iłowców z Sasina w otworach: a) L-1, b) K-1 
tość TOC z zakresu 5,74 $\div 11,87 \%$ wykazały utwory w interwale $2159,61 \div 2163,23 \mathrm{~m}$ (dokumentacja otworu B8-Z4). W otworze B-21/2 ogniwo iłowców bitumicznych z Jantaru o miąższości 15 m, w którym należy wyróżnić pakiet iłowców w interwale 1654,93 $\div 1661,0$ m, odznacza się najwyższym potencjałem generacyjnym i najwyższym nasyceniem wolnymi węglowodorami (TOC od $0,18 \%$ do $6,76 \%$ (dokumentacja wynikowa otworu B-21/2)).

\section{Utwory węglanowe ordowiku}

W otworze B-21/2 interpretacja krzywych geofizyki otworowej wykonana przez zespół Geofizyka Torun S.A. pokazuje, że warstwy wapieni ordowickich, w wydzielonych wkładkach, nasycone węglowodorami rezydualnymi charakteryzują się słabymi parametrami zbiornikowymi; ich średnie war- tości porowatości i przepuszczalności są bliskie wartościom parametrów odcięcia. (dla porowatości przyjmowano $<5 \%$ a dla przepuszczalności $<0,7 \mathrm{mD}$ (dokumentacja otworu)).

Podobnie zachowują się wapienie z Kopalina w analizowanych otworach basenu bałtyckiego.

\section{Utwory kambru}

Analizy wykonane przez laboratorium INiG - PIB (dokumentacja wynikowa otworu) dotyczyły łupków bitumicznych z kambru górnego (Cm3) z otworu B21/2. Próbki w liczbie $n=28$, pobrane $\mathrm{z}$ interwału $1755,0 \div 1787,96 \mathrm{~m}$, wykazały najwyższe wartości substancji organicznej w przeliczeniu na TOC w zakresie od 3,4\% do $15,02 \%$, przy średniej $9,86 \mathrm{wt} \%$. Osady te zawierają kerogen typu II z preferencjami generowania ropy naftowej (dokumentacja wynikowa otworu B21/2). W pozostałych otworach na szelfie (blok Rozewie - B8) nie stwierdzono kambru górnego.

Utwory kambru środkowego poziomu Paradoxides paradoxissimus (PP) nasycone są wodą złożową w zakresie od $44 \%$ do $90 \%$ (średnio 65\%). Skały zbiornikowe wykazują nieznaczne nasycenie węglowodorami resztkowymi, szczególnie w środkowej części serii złożowej (są to węglowodory nieruchome, pozostałe po procesach migracyjnych). Na rysunku 5 pokazano porównanie wyinterpretowanych i pomierzonych profilowań dla utworów kambru środkowego poziomu PP w otworze B8-Z4 odwierconym na szelfie.

Dane uzyskane z pomiarów geofizyki otworowej w odwiercie B8-Z5 wskazują na nasycenie utworów serii złożowej kambru środkowego poziomu PP głównie wodą złożową. Obecność węglowodorów nieruchomych wiązana jest ze strefami piaskowców, w których porowatość nie przekracza 5\% (dokumentacja wynikowa otworu B8-Z5, 2012).

W tablicy 2 przedstawiono interwały występowania utworów kambru w otworach basenu bałtyckiego.

Z powyższego zestawienia wynika (tablica 2 ), że kambr górny charakteryzuje się miąższościami od $1,0 \mathrm{~m}$ do $11,0 \mathrm{~m}$, ale w orzeczeniach końcowych dokumentacji nie był brany

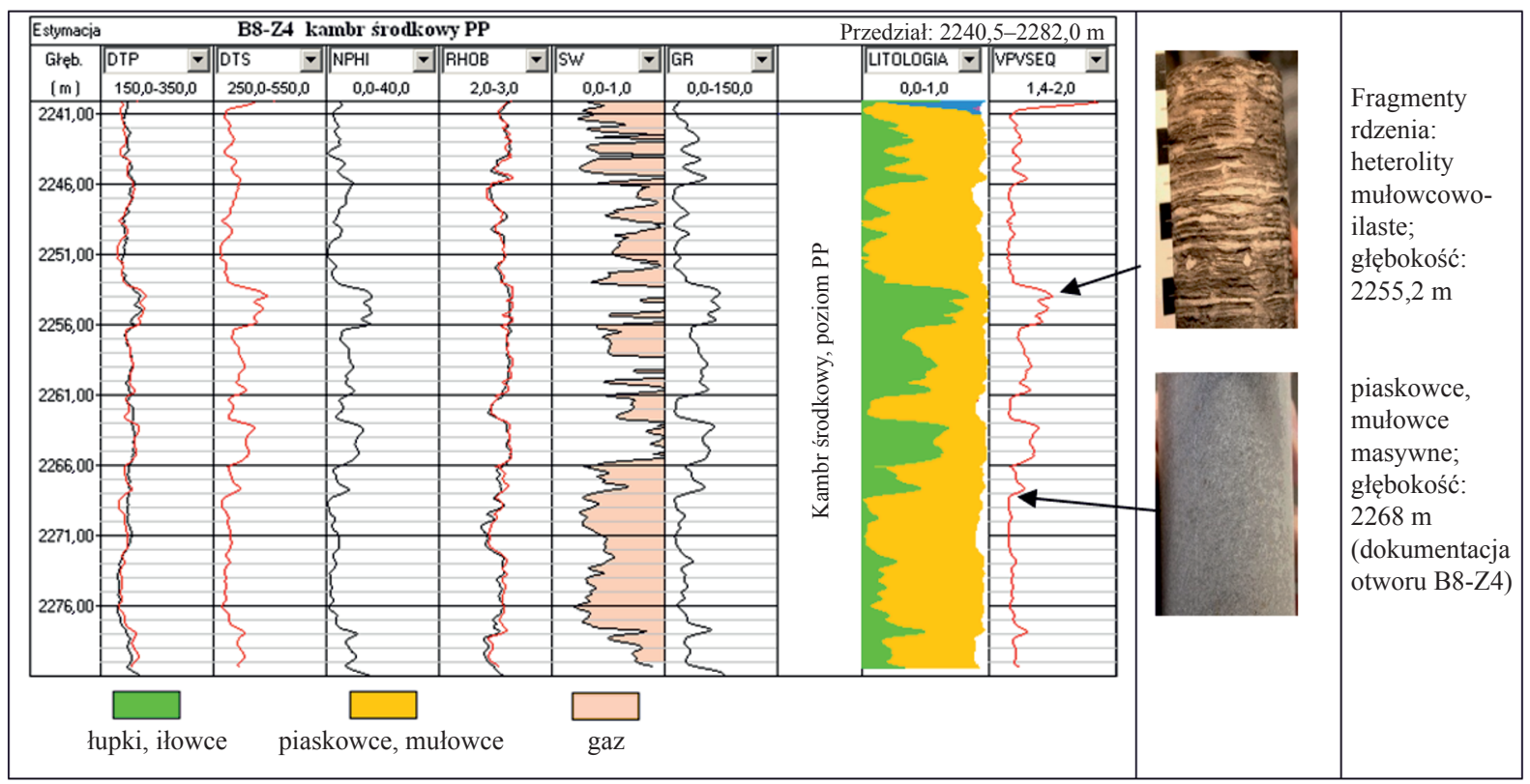

Rys. 5. Porównanie wyników pomiarów i interpretacji w interwale występowania utworów kambru środkowego poziomu Paradoxides paradoxissimus w otworze B8-Z4 
Tablica 2. Interwały występowania utworów kambru w analizowanych otworach basenu bałtyckiego

\begin{tabular}{|c|c|c|c|}
\hline Nazwa otworu & Kambr górny Cm3 & Kambr środkowy Cm2 & Uwagi \\
\hline L-1 & $2970,0 \div 2981,0 \mathrm{~m}$ & $2981,0 \div 3031,0 \mathrm{~m}$ & - \\
\hline O-2 & $2947,0 \div 2950,0 \mathrm{~m}$ & $2950,0 \div 3050,0 \mathrm{~m}$ & - \\
\hline K-1 & (brak?) & $3249,3 \div 3276,0 \mathrm{~m}$ & nieprzewiercony \\
\hline B-1 & $3726,0 \div 3727,0 \mathrm{~m}$ & $3727,0 \div 3757,9 \mathrm{~m}$ & nieprzewiercony \\
\hline W-1 & $3981,6 \div 3992,0 \mathrm{~m}$ & $3992,0 \div 4040,0 \mathrm{~m}$ & Raport_tg_2015 [19] \\
\hline
\end{tabular}

pod uwagę ze względu na słabe własności zbiornikowe (np. dokumentacja wynikowa otworu L-1).

Kambr środkowy w otworach basenu osiąga znaczne miąższości, od 26,7 $\mathrm{m}$ do prawie $100 \mathrm{~m}$.

Dla przykładu na rysunku 6 przedstawiono wyniki interpretacji i pomiarów w otworze K-1 zestawione z obrazem XRMI (fragment kambru środkowego).

We wszystkich analizowanych otworach basenu bałtyckiego kambr środkowy charakteryzuje się znikomą porowatością. Nasycenie węglowodorami, prawdopodobnie nieru- chomymi, jest bardzo zróżnicowane. Według raportu [19] jest to gaz zamknięty (tight gas). Obok wyników interpretacji na rysunku 6 przedstawiono fragment rdzenia uzyskanego z utworów kambru środkowego z otworu K-1. Z dokumentacji otworu K-1 wybrano zestawienie pomiarów sondą XRMI. Krzywe rejestrowane poszczególnymi ramionami (pady - ścieżka środkowa) ilustrują wzrost oporności pozornej naprzeciw zbitych piaskowców (strefy jasne), a w ilastych przewarstwieniach zaznaczają się wyraźne spadki oporności (strefy ciemne).

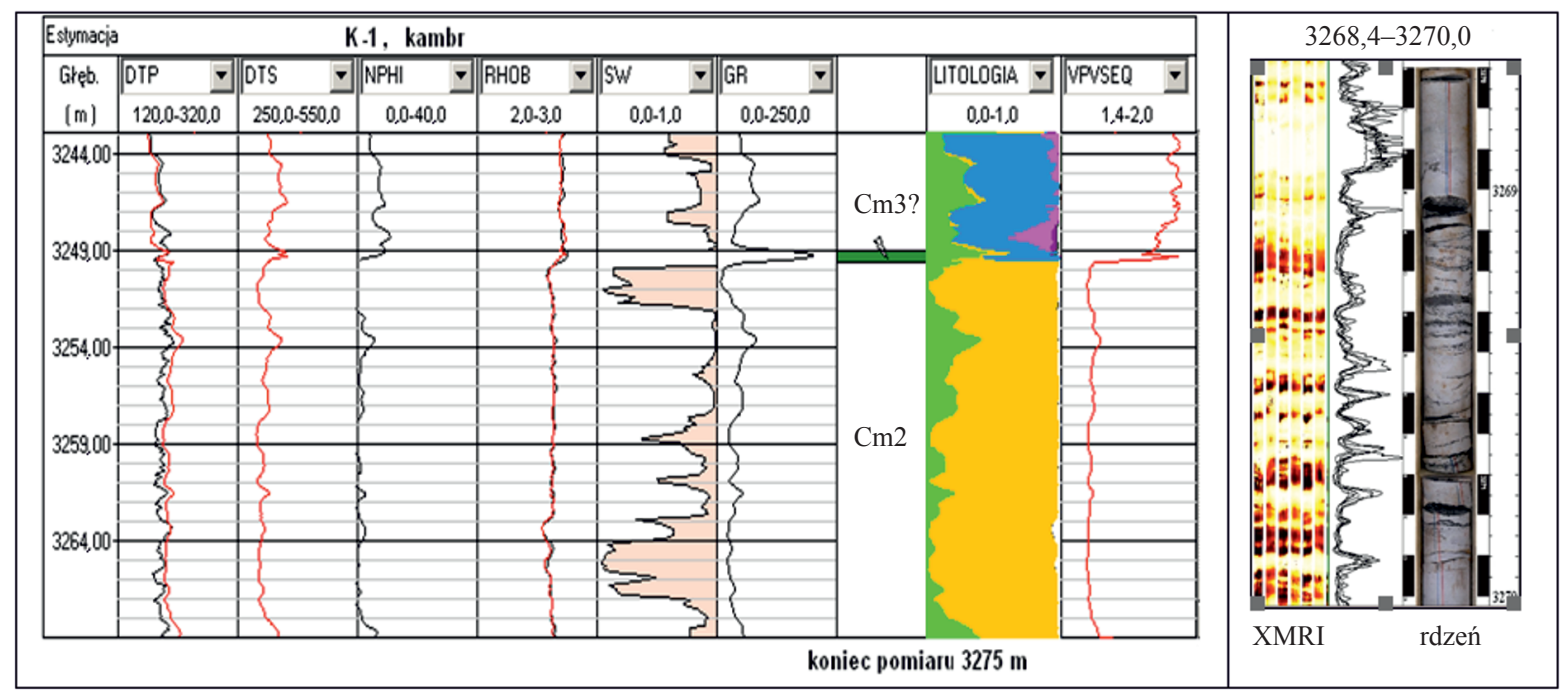

Rys. 6. Fragmenty obliczonych i pomierzonych krzywych w interwale występowania utworów kambru środkowego w otworze K-1. Nasycenie w objętości porów. Pokazano też zestawienie pomiarów XRMI oraz fragmenty rdzenia (dokumentacja wynikowa otworu K-1)

\section{Analiza wyników}

Wyniki badań parametrów sprężystych przedstawiono w postaci histogramów dla następujących serii:

- sejsmiczny poziom reperowy Sb wapieni z Redy (rysunki 7a, 7b),

- ogniwo iłowców bitumicznych z Jantaru (rysunki 7c, 7d),

- formacja iłowców z Sasina (rysunki 7e, 7f),

- wapienie z Kopalina (rysunki 7g, 7h),

- kambr środkowy Cm2 (rysunki 7i, 7j).

Kolorami zaznaczono poszczególne parametry określone $\mathrm{z}$ danych metod.
Skalę pionową na wszystkich histogramach przyjęto taką samą (od 0 do $65 \mathrm{GPa}$ ), aby można porównać wartości z poszczególnych grup parametrów w wybranych poziomach.

Analizując wartości średnie parametrów sprężystych przedstawionych na histogramach (rysunki 7a-7j), możemy zauważyć duże zróżnicowanie w poszczególnych seriach litostratygraficznych, ale stosunkowo niewielkie w pięciu otworach basenu bałtyckiego i trzech otworach położonych na szelfie.

Najniższe wartości średnie parametrów sprężystych obserwuje się w ogniwie iłowców bitumicznych z Jantaru. 

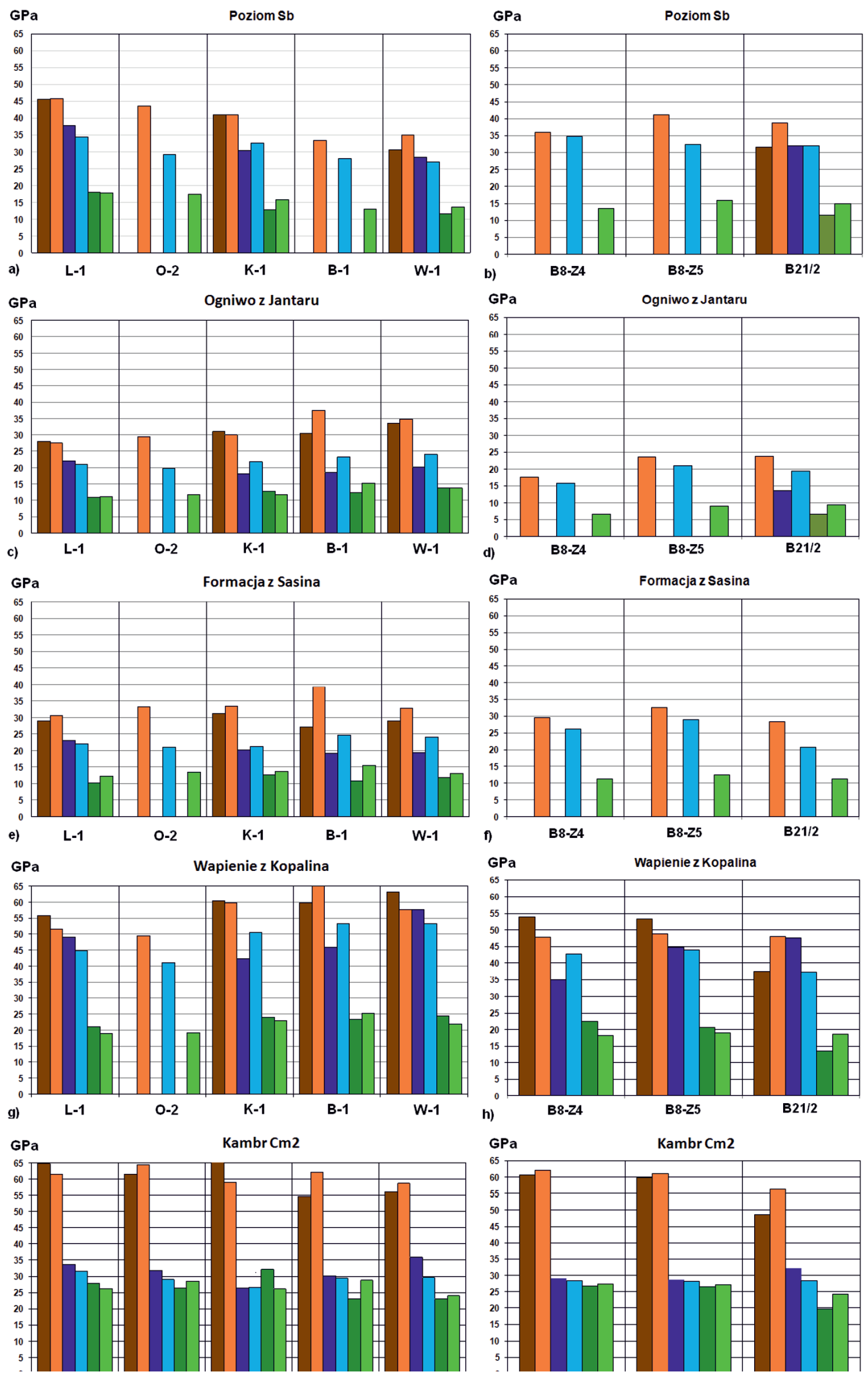

Rys. 7a-7j. Histogramy wartości średnich parametrów sprężystych określonych z obrazów falowych i modelu Biota-Gassmanna - kolejno modułów Younga (E, EEQ), odkształcenia objętości (K, KEQ) i postaci ( $\boldsymbol{\mu}, \mathrm{MIEQ})$ w analizowanych poziomach i otworach 
Wyjątek stanowi otwór W-1, w którym parametry sprężyste są prawie porównywalne $\mathrm{z}$ parametrami średnimi w formacji z Sasina w tym otworze. Niskie wartości średnich parametrów w ogniwie z Jantaru i podobnie w formacji z Sasina są wynikiem obecności kerogenu oraz podwyższonego zailenia w tych utworach.

Wapienie z Kopalina charakteryzują się wzrostem średnich wartości parametrów sprężystych, określonych zarówno na podstawie obrazów falowych, jak i uzyskanych z modelu (rysunek 7g, 7h).

Bardzo podobnie zachowują się średnie wartości parametrów w utworach kambru środkowego Cm2 (rysunek 7i, 7j), w których zaobserwowano najwyższe średnie moduły Younga, w trzech otworach położonych blisko siebie (L-1, O-2 i K-1). W połączeniu z obniżonymi wartościami współczynników Poissona może to świadczyć o wzroście kruchości (brittleness) tych utworów.

Na rysunku 8 pokazano histogramy stosunku średnich wartości VP/VS obliczonych z modelu Biota-Gassmanna dla tych samych poziomów litostratygraficznych. W takim zestawieniu widać wyraźnie zaniżone wartości w utworach piaskowcowych kambru środkowego Cm2 we wszystkich pięciu otworach w części lądowej basenu bałtyckiego, podobnie jak w trzech odwierconych na szelfie.

Najwyższe wartości VP/VS mają wapienie z Kopalina, we wszystkich pięciu otworach basenu (rysunek $8 \mathrm{a}$ ). Ich wartości zawierają się w przedziale od 1,867 do 1,94. Również poziom reperowy Sb osiąga wysokie wartości: $1,74 \div 1,887$. Nieco niższymi VP/VS charakteryzują się łupki bitumiczne z Jantaru i formacja łupków z Sasina. Najniższe wartości VP/VS obserwuje się w utworach kambru $\mathrm{Cm} 2$ - od 1,535 do 1,598.

W otworach na szelfie średnie wartości stosunków VP/VS dla sejsmicznego poziomu reperowego Sb zawierają się pomiędzy 1,83 i 1,972. Są to wartości określone tylko z modelu BG (brak danych z obrazów falowych) (rysunek 8b).
Bardziej wyrównane wartości średnich VP/VS można zaobserwować w iłowcach bitumicznych z Jantaru: od 1,848 z obrazu falowego w otworze B8-Z5 do 1,916 i 1,918 z modelu BG w otworach B8-Z5 i B8-Z4.

Iłowce z Sasina charakteryzują się porównywalnymi wartościami w tych samych otworach $(1,914$ i 1,917) i nieco obniżonymi VP/VS w otworze B21/2 (1,783 z BG i 1,806 z obrazów falowych).

W wapieniach z Kopalina w trzech przypadkach VP/VS przekracza 1,9 - w otworach B8-Z4, B8-Z5 z modelu BG i otworze B21/2 z obrazu falowego. Najniższa wartość średnia stosunku została określona z obrazu falowego w otworze B8-Z4.

Na tle tych poziomów, zawierających iłowce i wapienie, wyróżnia się zdecydowanie poziom piaskowcowy kambru środkowego PP, podobnie jak w otworach basenu. Wartości średnie stosunku obu prędkości wahają się między 1,546 i 1,560 w pięciu przypadkach. Tylko w otworze B21/2 z obrazu falowego uzyskano wartość 1,67, która wydaje się nieco zawyżona w przypadku litologii piaskowcowej (duża zawartość kwarcu).

W publikacjach $[1,3,6]$ przedstawiono, że stosunek VP/VS zawiera się w przedziale:

- dla piaskowców: $1,6 \div 1,76$,

- dla dolomitów: $1,75 \div 1,85$,

- dla wapieni: $1,85 \div 1,95$,

- dla utworów ilastych: $1,9 \div 1,99$.

Jednak obecność gazu może znacznie obniżać VP/VS (nawet przy małej objętości gazu w przestrzeni porowej [3]), natomiast zailenie podwyższa stosunek obu prędkości. $\mathrm{Na}$ rysunku 9 zaprezentowano zależność VP w funkcji SW dla warstw piaskowca o różnym stopniu zailenia (Vsh od 0,144 do 0,343 ) i porowatości (PHI od 17,3\% do 25,6\%). Można zauważyć spadek krzywych w miarę wzrostu nasycenia wodą SW od 0 do 0,8 (a tym samym SG od 1 do 0,2). Krzywa osiąga minimum w pobliżu $\mathrm{SW}=0,8$, potem gwałtownie wzrasta do $\mathrm{SW}=1$. a)

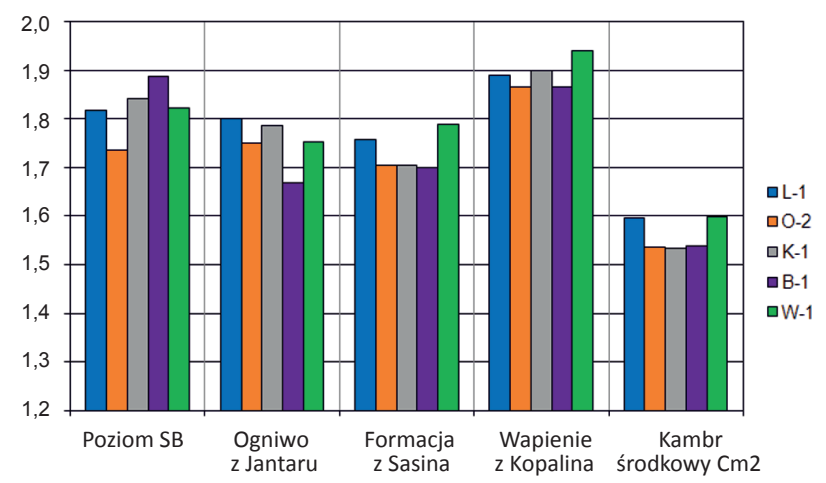

b)

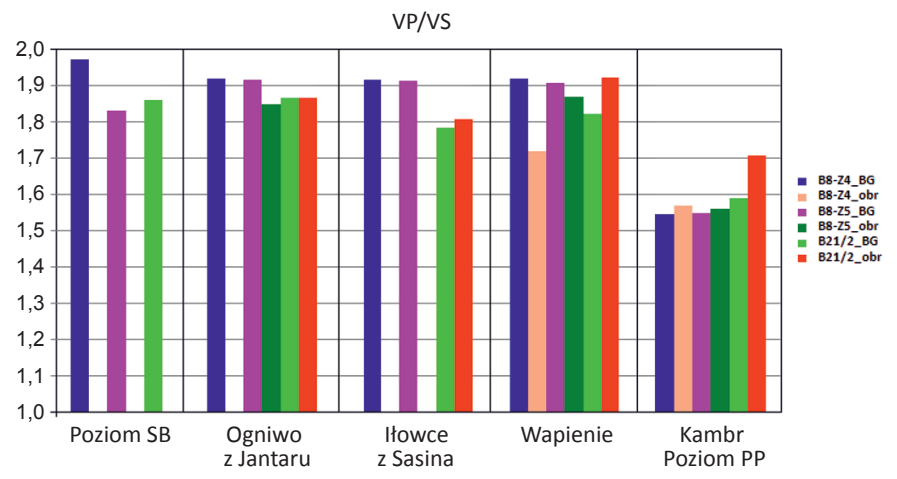

Rys. 8. Histogramy stosunku VP/VS obliczone modelem Biota-Gassmanna w wybranych seriach litostratygraficznych: a) w otworach basenu bałtyckiego, b) wierconych na szelfie 
Ponieważ VS nie wykazuje zmian ze wzrostem nasycenia, stosunek VP/VS przy $\mathrm{SW}=0,8$ również osiąga minimum przy tym nasyceniu. Tak więc minimalna objętość gazu $(\mathrm{SG}=0,2)$ może w znacznym stopniu zaburzyć interpretację sejsmicznego obrazu falowego, dając podobny obraz jak przy znacznym jego nasyceniu $[5,15]$.

Takie zachowanie się prędkości fali podłużnej ze zmianami nasycenia porów wodą i gazem (powietrze) potwierdzają badania laboratoryjne [7].

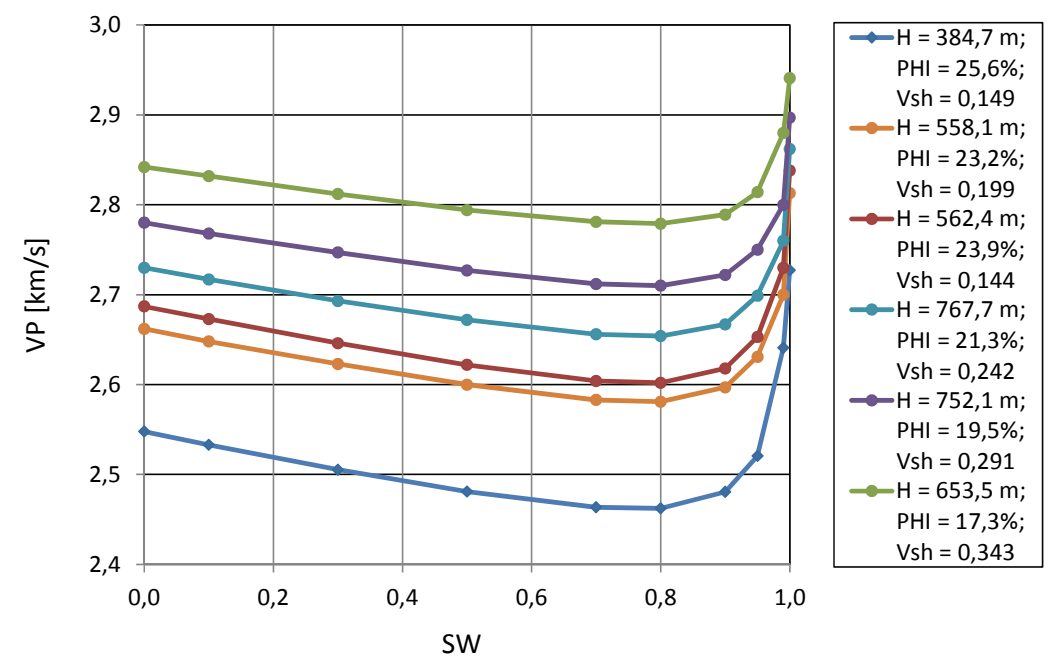

Rys. 9. Relacja VP vs SW dla utworów piaskowcowo-ilastych o zróżnicowanych porowatościach (PHI) i zaileniu (Vsh) [3]

\section{Ocena kruchości skały}

Mechaniczne własności łupków ilastych odgrywają zasadniczą rolę w prognozowaniu zabiegów szczelinowania hydraulicznego i udostępnianiu węglowodorów ze skał zbiornikowych o niskich przepuszczalnościach. Skały te charakteryzują się zróżnicowaną „kruchością” (brittleness), którą można rozpatrywać w aspekcie składu mineralnego i parametrów sprężystych.

Jak przedstawiono w pracy [16], kruchość jest funkcją wielu czynników. Szczególnie zależy od litologii, naprężeń kompensacyjnych i tensyjnych (ściskających i rozciągających), anizotropii mechanicznej, temperatury, ciśnienia i typu cieczy porowej, procesów kompakcji i diagenezy oraz zawartości materii organicznej (TOC).

Obecność minerałów kwarcu czy węglanów zwiększa kruchość skały w przeciwieństwie do substancji ilastej, w której przeważają deformacje plastyczne, prowadzące do osłabienia twardości szkieletu [10]. Z drugiej strony cementacja węglanowa może ograniczać przepustowość już istniejących szczelin. Duża ilość węglanów oraz pęczniejących minerałów ilastych sprawia znaczne problemy przy zabiegach udostępniania złóż.

W literaturze pojawia się wiele definicji kruchości skał łupkowych. W tablicy 3 przedstawiono wybrane wzory opisujące wskaźnik kruchości (BI - brittleness index).

"gdzie:

$V_{Q z}$ - zawartość kwarcu,

$V_{D o l}$ - zawartość dolomitu,

$V_{C a}$ - zawartość wapieni,

$V_{C l y}$ - zawartość substancji ilastej,
Tablica 3. Wzory opisujące wskaźnik kruchości skały BI

\begin{tabular}{|c|c|c|c|}
\hline \multirow{4}{*}{ Typ } & $\begin{array}{c}\text { Numer } \\
\text { wzoru }\end{array}$ & Wzór & Autor \\
\hline \multirow{4}{*}{$\begin{array}{l}\text { Skład } \\
\text { mineralny }\end{array}$} & $(1 \mathrm{a})$ & $B I_{\text {mineral }}=\frac{V_{Q z}}{V_{Q z}+V_{C a}+V_{C l y}}$ & {$[11]$} \\
\cline { 2 - 4 } & $(1 \mathrm{~b})$ & $B I_{\text {mineral }}=\frac{V_{Q z}+V_{D o l}}{V_{Q z}+V_{D o l}+V_{C a}+V_{C l y}+V_{T o C}}$ & {$[18]$} \\
\cline { 2 - 4 } & $(1 \mathrm{c})$ & $B I_{\text {mineral }}=\frac{V_{Q z}+V_{S k}+V_{D o l}+V_{C a}}{V_{Q z}+V_{D o l}+V_{S k}+V_{C a}+V_{C l y}+V_{T O C}+V_{P i r}}$ & {$[12]$} \\
\hline \multirow{2}{*}{$\begin{array}{l}\text { Parametry } \\
\text { sprężyste }\end{array}$} & $(2)$ & $B I_{\text {elast }}=\frac{E_{B I}+v_{B I}{ }^{* *}}{2}$ & {$[9]$} \\
\cline { 2 - 4 } & $(3)$ & $B I_{\lambda}=\frac{\lambda}{\lambda+2 \mu}$ & {$[8]$} \\
\hline
\end{tabular}

$V_{\text {TOC }}$ - zawartość materii organicznej,

$V_{S k}$ - zawartość skaleni,

$V_{\text {Pir }}$ - zawartość pirytu.

Obecność materii organicznej powoduje zwiększenie plastyczności skały, podobnie jak wzrost substancji ilastej.

${ }^{* *}$ BI można wyrazić poprzez parametry sprężystości: moduł Younga (E) i współczynnik Poissona (v) [9].

$$
E_{B I}=\frac{E_{o b s}-E_{\min }}{E_{\text {maks }}-E_{\min }} \quad v_{B I}=\frac{v_{o b s}-v_{\min }}{v_{\text {maks }}-v_{\min }}
$$

Parametry występujące we wzorze (2a) zostały określone na podstawie interpretacji obrazów falowych, względnie obliczone programem Estymacja TP z użytym modelem Biota-Gassmanna.

Podwyższone wartości modułów Younga i obniżone współczynniki Poissona w łupkach charakteryzują strefy o potencjalnych zdolnościach do pękania i kruszenia się skał (brittleness). 
Na rysunku 10 pokazano, dla przykładu, wykres krzyżowy modułu Younga i współczynnika Poissona, określonych z modelu BG, dla wybranych formacji w otworze O-2. Duża strzałka wskazuje kierunek wzrostu kruchości skały (brittleness). Skala modułu Younga jest odwrócona. Współczynniki Poissona zmieniają się dla iłowców z Jantaru i formacji z Sasina od 0,17 do 0,33, a moduł Younga od $18 \mathrm{GPa}$ do $60 \mathrm{GPa}$.

Zakres zmian plasuje iłowce ogniwa z Jantaru i łupki z Sasina w strefie utworów o średniej i niskiej kruchości. Lokalnie niektóre punkty mają nieco inne wartości.

Bardzo podobnie zachowują się moduły Younga i współczynniki Poissona w przypadku iłowców z Jantaru i formacji z Sasina w innych otworach basenu bałtyckiego [2].

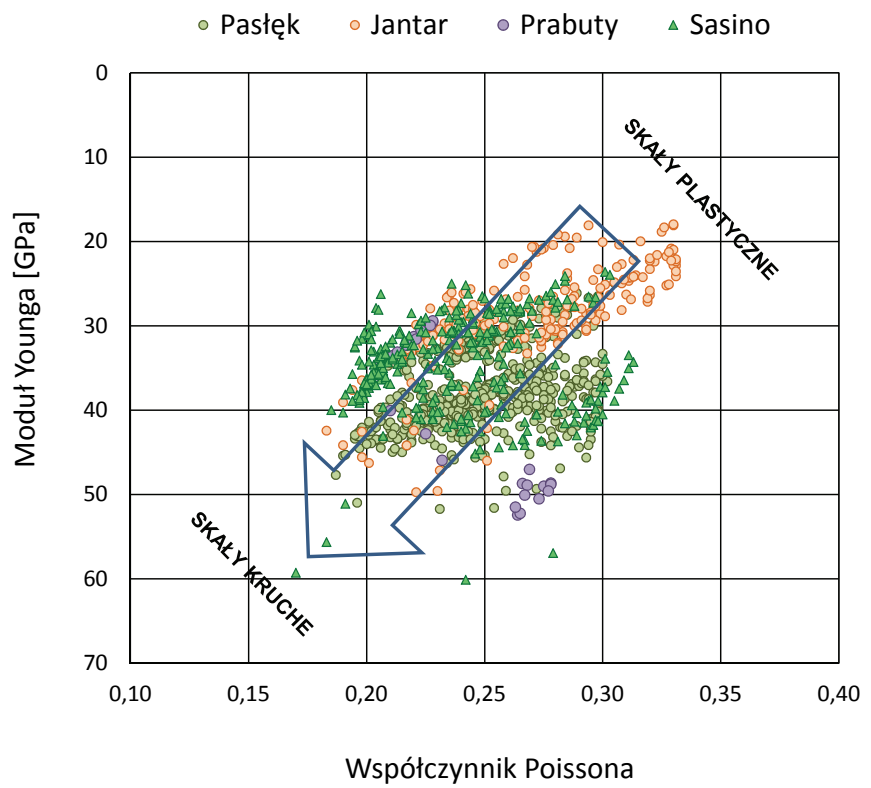

Rys. 10. Wykres krzyżowy: moduł Younga vs współczynnik Poissona określone $\mathrm{z}$ modelu BG dla wybranych formacji $\mathrm{z}$ otworu $\mathrm{O}-2$
Stosując wzory (1c) i (2), (2a) obliczono wartości wskaźnika kruchości skały $B I_{\text {mineral }}$ oraz $B I_{\text {elast }}$ dla utworów syluru i ordowiku. Na rysunku 11 zaprezentowano porównanie obu wskaźników kruchości w otworze O-2.

Należy zauważyć, że utwory ilasto-margliste syluru i ordowiku charakteryzują się dużą zmiennością obliczonego parametru kruchości $B I_{\text {elast }}$ Interesujące, jako potencjalne sweet spots, osady ogniwa iłowców bitumicznych z Jantaru i formacja iłowców z Sasina są bardzo zróżnicowane i mają na ogół obniżone wartości $B I_{\text {elast }}$. Można je z tego względu zaliczyć do poziomów, w których obserwuje się nie tylko deformacje sprężyste, ale i plastyczne, prowadzące do osłabienia twardości szkieletu. Wnioski te dotyczą wszystkich analizowanych otworów basenu.

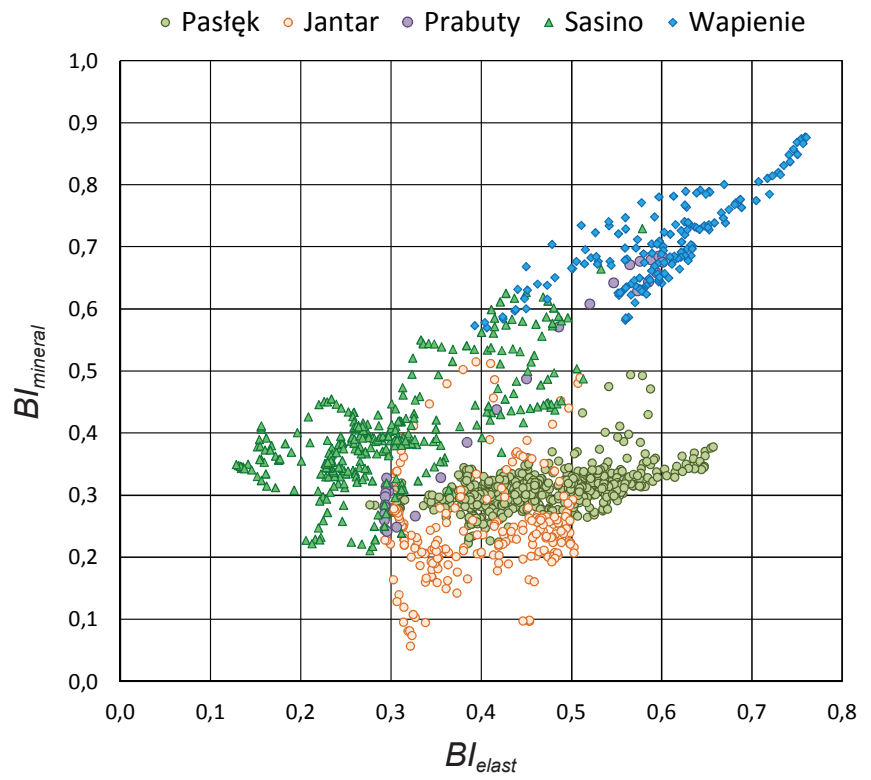

Rys. 11. Porównanie wskaźników kruchości obliczonych ze składu mineralnego $B I_{\text {mineral }}$ oraz z parametrów sprężystych $B I_{\text {elast }}$ dla formacji syluru i ordowiku $\mathrm{z}$ otworu $\mathrm{O}-2$

\section{Wykorzystanie innych parametrów sprężystych do oceny kruchości skał}

Obliczono również inny parametr sprężysty charakteryzujący badane obiekty litostratygraficzne - stałą Lamégo $\lambda$ (lambda), według wzoru:

$$
\lambda=\frac{E \cdot v}{(1+v) \cdot(1-2 v)}
$$

Na podstawie wartości $\lambda$ i modułu $\mu$ można obliczyć wskaźnik kruchości skały ( $B I_{\lambda}$ - wzór (3) w tablicy 3) [8].

Na rysunku 12 zestawiono wskaźniki kruchości utworów formacji z Pasłęka, ogniwa z Jantaru, formacji z Prabut, formacji z Sasina i wapieni z Kopalina obliczone różnymi metodami, przy wykorzystaniu wzorów (1c), (2), (2a) oraz (3) i (3a). Dobrą zgodność obliczonych parametrów można za- obserwować w formacji z Pelplina i częściowo w utworach wapieni z Kopalina. Duża rozbieżność pomiędzy $B I_{\text {mineral }}$ i pozostałymi zaznacza się $w$ interwałach formacji z Pasłęka i ogniwa z Jantaru. Może to świadczyć o nieuwzględnieniu w obliczeniach jakiegoś minerału. Osady ogniwa z Jantaru, a także formacji z Sasina charakteryzują się generalnie obniżeniem wartości BI.

Parametry Lamégo $(\lambda, \mu)$, wykorzystane do obliczenia $B I_{\lambda}$, dostarczają dodatkowej informacji, która może być stosowana w celu identyfikacji stref nasyconych węglowodorami. Wartość $\lambda$ jest „czuła” na zawartość medium w skale, podczas gdy wartość modułu odkształcenia postaci $(\mu)$ reaguje na szkielet skały i jego sztywność. 


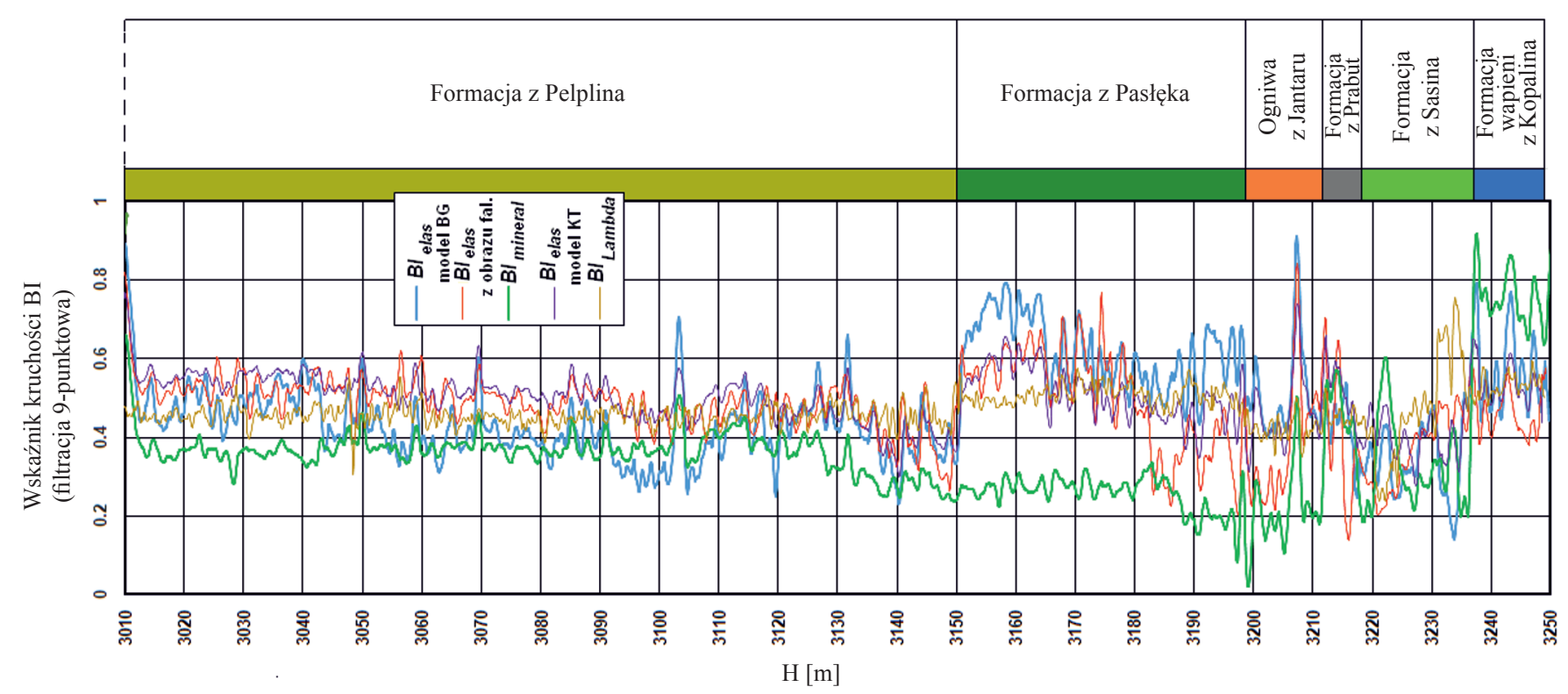

Rys. 12. Zestawienie wskaźników BI obliczonych różnymi metodami dla utworów: formacji z Pasłęka, ogniwa z Jantaru, formacji z Prabut, formacji z Sasina i wapieni z Kopalina w otworze K-1

\section{Podsumowanie}

Przeanalizowano szczegółowo wyniki parametrów sprężystych obliczonych przy użyciu modelu Biota-Gassmanna w programie Estymacja TP i wyniki interpretacji z pomiarów sondy dipolowej.

Skupiono się na kilku seriach litostratygraficznych:

- sylurskich mułowcach wapnistych z Redy, będących sejsmicznym poziomem reperowym (ludlow),

- ogniwie iłowców bitumicznych z Jantaru, należącym do dolnego syluru (landower),

- formacji iłowców z Sasina (ordowik środkowy, karadok),

- formacji wapieni z Kopalina (ordowik, lanwirn),

- utworach kambru środkowego (kambr, $\mathrm{Cm} 2$, poziom PP). Na histogramach charakteryzujących poszczególne poziomy zamieszczono wartości średnie modułów Younga, modułów odkształcenia objętości i postaci. Dodatkowo zestawiono histogramy wartości średnich dla stosunku VP/VS.

Zauważono duże podobieństwo $\mathrm{w}$ wartościach parame- trów sprężystych $\mathrm{w}$ analizowanych poziomach, zarówno w basenie bałtyckim, jak i w strefie szelfowej.

Właściwości mechaniczne skał zmieniają się wraz ze zmianami litologicznymi. Dla skał ilastych właściwości te są gorsze, skała wykazuje charakter bardziej plastyczny, podczas gdy dla skał piaskowcowych oraz domieszek węglanowych bardziej kruchy.

W przypadku planowania zabiegu szczelinowania pod uwagę powinien być brany parametr kruchości (brittleness).

Zestawienie modułów Younga i współczynnika Poissona w formie wykresów krzyżowych pozwala na jakościową ocenę kruchości badanych formacji.

Przedstawione charakterystyki parametrów sprężystych mogą być wykorzystane w modelowaniach sejsmicznych do badania zmienności poziomów stratygraficznych i wyjaśnienia szeregu problemów pojawiających się w zintegrowanej interpretacji danych geofizyki otworowej i sejsmicznych pól falowych.

Prosimy cytować jako: Nafta-Gaz 2017, nr 8, s. 558-570, DOI: 10.18668/NG.2017.08.03

Artykuł nadesłano do Redakcji 17.03.2017 r. Zatwierdzono do druku 22.06.2017 r.

Praca została zrealizowana w ramach projektu Blue Gas pt.: Metodologia wyznaczania sweet spoot'ów na podstawie własności geochemicznych, petrofizycznych, geomechanicznych w oparciu o korelację wyników badań laboratoryjnych z pomiarami geofizycznymi i model generacyjny 3D - (MWSSSG) Polskie Technologie dla Gazu Łupkowego, Zadanie 10: Adaptacja do warunków polskich metodologii wyznaczania sweet spotów na podstawie korelacji pomiarów geofizycznych z rdzeniami wiertniczymi, finansowanego przez Narodowe Centrum Badań i Rozwoju.

Autorka dziękuje Polskiemu Górnictwu Naftowemu i Gazownictwu S.A. w Warszawie za udostęnienie danych wykorzystanych w niniejszym artykule. 


\section{Literatura}

[1] Bała M.: Analiza obrazu falowego zarejestrowanego przy profilowaniu akustycznym w odwiercie pod katem oceny parametrów sprężystych i zbiornikowych skat. Zeszyty Naukowe AGH, Geofizyka Stosowana 1989, 1247, nr 3, s. 1-166.

[2] Bała M.: Określanie parametrów kruchości lupków ilastych na podstawie wyników interpretacji danych geofizyki otworowej, modelowań teoretycznych oraz pomiarów laboratoryjnych. Międzynarodowa Konferencja Naukowo-Techniczna Geopetrol 2016, Zakopane-Kościelisko, 19-22.09.2016.

[3] Bała M.: The influence of pore media distribution on the elastic parameters of rocks in Miocene sediments (Carpathian Foredeep, Poland, B deposit). Geology, Geophysics \& Environment 2012, vol. 41, nr 2, s. 155-167.

[4] Bała M., Cichy A.: Metody obliczania prędkości fal P i S na podstawie modeli teoretycznych i danych geofizyki otworowej-program Estymacja. Monografia. Wydawnictwa AGH 2006, s. 1-89.

[5] Bała M., Cichy A., Jarzyna J., Mortimer Z., Pietsch K., Puskarczyk E., Marzec P., Witek K., Niepsuj M., Zalewska J.: Modelowania teoretyczne $i$ empiryczne wpływu zmiennego ciśnienia i nasycenia gazem na parametry sprężyste, gęstośc i oporność skat dla oceny przepuszczalności z danych geofizyki otworowej. Projekt badawczy nr NN525 363537 (archiwum wewnętrzne), 2012.

[6] Domenico S.N.: Rock lithology and porosity determination from shear and compressional wave velocity. Geophysics 1984, vol. 49, nr 8, s. 1188-1195.

[7] Enders A.L., Knight R.: The effect of pore scale fluid distribution on the physical properties of partially saturated tight sandstones. J. Appl. Physics 1989, vol. 69, s. 1091-1098.

[8] Goodway B., Perez M., Varsek J., Abaco C.: Seismic petrophysics and isotropic, anisotropic AVO methods for unconventional gas exploration. The Leading Edge 2010, vol. 29, nr 12, s. $1500-1508$.

[9] Grieser B., Bray J.: Identification of production potential in unconventional reservoirs. SPE Production and Operations Symposium 2007, SPE 106623.

[10] Jarosiński M.: Mechaniczne właściwości skat tupkowych. Serwis Informacyjny Państwowej Służby Geologicznej, Państwowy Instytut Geologiczny - Państwowy Instytut Badawczy 2013, http://infolupki.pgi.gov.pl (dostęp: 2016).

[11] Jarvie D.M., Hill R.J., Ruble T.E., Pollastro R.M.: Unconventional shale-gas systems: the Mississippian Barnett Shale of North-Central Texas as one model for thermogenic shale-gas assessment. AAPG Bulletin 2007, vol. 91, s. 475-499.

[12] Jin X., Shah S.N., Roegiers J.C., Zhang B.: Fracability evaluation in shale reservoirs - an integrated petrophysics and geomechanics approach. SPE Hydraulic Fracturing Technology Conference: Woodlands, Texas, Society of Petroleum Engineers 2014.
[13] Kiersnowski H.: Geological Environment of Gas-Bearing Shales. [W:] Nawrocki J.: Shale gas as seen by Polish Geological Survey. Państwowy Instytut Geologiczny - Państwowy Instytut Badawczy 2013, s. 26-31.

[14] Kotarba M. (red.): Systemy naftowe i perspektywy poszukiwawcze utworów staropaleozoicznych polskiego sektora morza bałtyckiego między Łeba a Kamieniem Pomorskim. AGH, Kraków 2008 (opracowanie archiwalne).

[15] Marzec P., Niepsuj M., Bała M., Pietsch K.: The Application of Well Logging and Seismic Modeling to Assess the Degree of Gas Saturation in Miocene Strata (Carpathian Foredeep, Poland). Acta Geophysica 2014, vol. 62, nr 1, s. 83-115.

[16] Perez R., Marfurt K.: Calibration of Brittleness to Elastic Rock Properties via Mineralogy Logs in Unconventional Reservoirs. Adapted from oral presentation given at AAPG International Conference and Exhibition, Cartagena, Colombia 8-11.09.2013.

[17] Sowiżdżał K., Stadtmüller M., Lis-Śledziona A., Kaczmarczyk W.: Analiza porównawcza formacji tupkowych $w$ wybranych strefach basenu battyckiego na podstawie interpretacji danych otworowych $i$ wyników modelowania geologicznego 3D. Nafta-Gaz 2016, nr 11, s. 891-900, DOI: 10.18668/ NG.2016.11.01

[18] Wang F.P., Gale J.F.: Screening criteria for shale-gas system. Gulf Coast Asso. Geol. Soc. Trans. 2009, vol. 59, s. 779-793.

[19] Wójcicki A., Kiersnowski H., Dyrka I., Adamczak-Biały T., Becker A., Głuszyński A., Janas M., Kozłowska A., Krzemiński L., Kuberska M., Pacześna J., Podhalańska T., Roman M., Skowroński L., Waksmundzka M.I.: Prognostyczne zasoby gazu ziemnego $w$ wybranych zwięzłych skatach zbiornikowych Polski. Państwowy Instytut Geologiczny - Państwowy Instytut Badawczy, Warszawa 2014, http://infolupki.pgi. gov.pl/sites/default/files/czytyelnia pliki/1/raport tg_2015. pdf (dostęp: 2016).

[20] Projekt Blue Gas MWSSSG, Zadanie 10: Adaptacja do warunków polskich metodologii wyznaczania sweet spotów na podstawie korelacji pomiarów geofizycznych z rdzeniami wiertniczymi. Kierownik zadania: J. Jarzyna, 2017. Opracowanie końcowe.

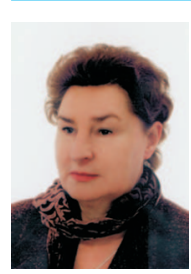

Prof. dr hab. inż. Maria BAŁA

Akademia Górniczo-Hutnicza im. Stanisława Staszica w Krakowie, Wydział Geologii, Geofizyki i Ochrony Środowiska, Katedra Geofizyki. al. Mickiewicza 30, 30-059 Kraków

E-mail:bala@geol.agh.edu.pl 